\title{
Caracterização Microbiológica de Erva-Mate (llex Paraguariensis St. Hil.) Beneficiada Na Região do Médio Alto Uruguai - RS
}

Bruna Martins Parodes (I), Giovana Paula Zandoná (I), Josiane

Souza Santos (I), Roberta Cancian (I), Marilaine Fernandes (I), Mônica Turchetto (I), Magda Aita Monego (I), Ana Eucares von Laer

(I), Valéria Maria Limberger-Bayer (I)

(I) UFSM - Universidade Federal de Santa Maria (Linha 7 de setembro s/n BR 386 Km 40 Cx. Postal 54 Cep 98400000 Fred.Westphalen)

\section{Resumo}

Erva-mate é o produto obtido exclusivamente pelas folhas e ramos de Ilex paraguariensis St. Hil., por processo de secagem e fragmentação e destinado ao preparo de "chimarrão" ou "tererê" podendo ser adicionado ou não de açúcar. Apesar do processamento ser relativamente simples, quando comparada às demais agroindústrias, ainda há muito a ser estudado e aprimorado na obtenção de erva-mate. Neste contexto, o objetivo do trabalho foi a caracterização microbiológica da erva-mate beneficiada para consumo na forma de chimarrão na região do Médio Alto Uruguai no Rio Grande do Sul. As amostras de cada etapa do processo (após o cancheamento e produto final já embalado) foram coletadas em quatro ervateiras (E1, E2, E3 e E4) da região. Posteriormente, foram avaliados coliformes a $45^{\circ} \mathrm{C}$, bolores e leveduras, mesófilos e Salmonella spp. A RDC 12/2001, que trata sobre padrões microbiológicos para alimentos, estabelece apenas a ausência de Salmonella spp. em $25 \mathrm{~g}$ do produto e para esse quesito todas as amostras encontraram-se dentro dos padrões. $\mathrm{Na}$ contagem de bolores e leveduras, todas as amostras avaliadas apresentaram resultados abaixo do limite máximo estabelecido pela Organização Mundial da Saúde $\left(10^{4} \mathrm{UFC} \mathrm{x} \mathrm{g}^{-1}\right)$, demonstrando maior possibilidade de manter as características inalteradas durante o prazo de vida útil do

\footnotetext{
Referência:

Bruna Martins Parodes, Giovana Paula Zandoná, Josiane Souza Santos, Roberta Cancian, Marilaine Fernandes, Mônica Turchetto, Magda Aita Monego, Ana Eucares von Laer, Valéria Maria Limberger-Bayer. Caracterização Microbiológica de Erva-Mate (Ilex Paraguariensis St. Hil.) Beneficiada Na Região do Médio Alto Uruguai - Rs. In: Anais do $12^{\circ}$ Congresso Latinoamericano de Microbiologia e Higiene de Alimentos - MICROAL 2014 [= Blucher Food Science Proceedings, num.1, vol.1]. São Paulo: Editora Blucher, 2014. DOI $10.5151 /$ foodsci-microal-154
} 
produto. Para as demais análises não há limites estabelecidos pela legislação, no entanto, como o produto é preparado e consumido em temperaturas que não causarão a eliminação de micro-organismos ou parte deles, as análises foram realizadas para avaliar as condições microbiológicas gerais da erva-mate e a segurança alimentar. Com relação aos coliformes termotolerantes, as amostras de produto final das ervateira E1, E2, E4 e também a amostra cancheda da ervateira E2 obtiveram enumeração de ${ }^{-1}$. Para análise de mesófilos os resultados para as amostras de erva-mate cancheada variaram de $0,5 \times 10^{3}$ a 7,2 $\times 10^{2}$ UFC $\times$ g $^{-1}$ e no produto pronto de $1,6 \times 10^{2}$ até 5,3 $\times 10^{4} \mathrm{UFC} \times \mathrm{g} \mathrm{g}^{-1}$. De acordo com os resultados, percebe-se que a erva-mate pode ser consumida sem oferecer riscos aos consumidores, contudo, o aumento na contagem de mesófilos no produto final salienta a importância de maiores estudos envolvendo as agroindústrias e o processamento, na garantia de um beneficiamento com uso das Boas Práticas de Fabricação.

Palavras-Chave: análises microbiológicas, processamento erva-mate, qualidade

Agência de Fomento: $\mathrm{CNPq}$ 